\title{
8 Recommended reading
}

Wild Orchids of Britain, V. S. Summerhayes, Collins, New Naturalist series, 2nd edition, London (1968). Though now slightly out of date in a few ways, this is an absolute must for anyone seeking depth in his knowledge of our orchids.

An Excursion Flora of the British Isles, Clapham, Tutin and Warburg, Cambridge University Press, 2nd edition, Cambridge (1968). This is a shorter and slightly more up-to-date version of the standard British Flora, though it is now distinctly out-of-date in some orchid respects. Plants and their parts are fully and technically described, and the tyro plantsman may find the jargon well-nigh impenetrable.

Europaeische und Mediterrane Orchideen, H. Sundermann, Bruecke Verlag Kurt Schmersow, 2nd edition, Hildesheim (1975). Perhaps the best book dealing with European orchids outside these islands, it is very well illustrated but unfortunately the text is in German. There is no book in English on this topic which can be wholly recommended, though Orchids of Europe, A. Duperrex, Blandford (1961), can be useful at times.

The Pollination of Plants, M. C. F. Proctor and P. Yeo, Collins, New Naturalist series, London (1973). The subject is as stated, but much space is devoted to orchids and the illustrations are excellent.

Natural History Photography, D. M. T. Ettlinger et al., Academic Press, London (1974). The chapter on plant photography is by M. C. F. Proctor and is considerably more detailed than the treatment here.

Finding Wild Flowers, R. S. R. Fitter, Collins, London (1971). While the book deals with all our wild flowers, it gives some very useful localities for particular types of habitat in each county or small group of counties. For the commoner species of orchid, sites can readily be deduced from some of these, but the author is properly careful not to mention any of the major rarity sites. 